\title{
Measuring the Sufficiency of the Infusion of Generic Skills of Real Estate Graduates by Training
}

\author{
W. R. Anthony Jiram, A. A. Bujang, H. Abu Zarin, and A. Abdul Latib
}

\begin{abstract}
It is necessary for students to acquire relevance skills that will improve their job prospects and make them more competitive in the job market. Subsequently, the formal curriculum of the real estate program lacks emphasis on the assimilation of generic skills in the curriculum. It identified the need for generic skills assessment of real estate graduate. Therefore, the intent of this study was to assess the sufficiency of the infusion of real estate graduate's generic skills in training program. The study concentrates on the acquisition of generic skills of real estate graduate in the process of teaching and learning provided the initial evidence of the 'Embedded Model'. The research refers to the Malaysian model on the implementation of generic skills in higher education. The findings were verified through focus group discussion with the various stakeholders in real estate education.
\end{abstract}

Index Terms - Generic skills, graduates, real estate, training.

\section{INTRODUCTION}

Dasso and Woodward [1] stressed that little accentuation was positioned upon real estate education. In recent years, growing attention has been focused on real estate education. Therefore, to execute the obligations of Valuation and Property Services Department, the main concentration of training in the real estate profession has moved to a wider spectrum. In order to meet the current needs of industry, real estate education needed to be constantly reviewed and reevaluated. It is very important for educators to clarify the requirements of the industry to make sure the training provided is appropriate and proficient at preparing students for the challenges to be faced [2].

Issue that had received wide coverage in Malaysia is the employability or marketability of graduates from public universities, and many other countries have also acknowledged that higher education has failed to meet the expectations of employers [3]-[6].

The rationales cited for the depleted redundancy prospects of public university graduates are that they are deficient in linguistic such as English proficiency in both verbal and written, technical skills, poorly prepared for the job market,

Manuscript received August 14, 2014; revised Ocotober 19, 2014. This work was supported by Ministry of Education and Universiti Teknologi Malaysia under the Exploratory Research Grant Scheme Vot.4L081.

W. R. Anthony Jiram and H. Abu Zarin are with Universiti Teknologi Malaysia, Malaysia (e-mail: wilson.rangga@live.com.my, hasmah@utm.my).

A. A. Bujang is with the Department of Ral Estate, Faculty of Geoinformation and Real Estate, Universiti Teknologi Malaysia, Malaysia, (e-mail: ahamadariffian@utm.my).

A. Abdul Latib is with the Department of Technical and Engineering, Faculty of Education, Universiti Teknologi Malaysia, Malaysia (e-mail: p-azlan@utm.my). plus cognitive abilities such as problem-solving and analytical thinking [7]-[11].

As some public universities continue using Malay as the medium in curriculum, in particular, the employers remain undecided on the enthusiasm of graduates, predominantly in written and oral communication. Subsequently, the formal curriculum of public universities lacked focus on the assimilation of generic skills in the curriculum [12], [13].

Furthermore, few research in real estate have asked the real estate professionals to figure out what to put in real estate programs to enrich the education for student and real estate practitioners [14], [15]. Moreover, two articles discovered some perceptivity into the imperative aspects of core competencies and skills in developing real estate syllabus [16], [17].

\section{LITERATURE REVIEWS}

\section{A. The Evolution of Real Estate Education}

Real estate education in Malaysia was influenced by the British system as most of the real estate system such as real estate laws, planning and taxation. British real estate education is based on the general practice surveying, and planning and development surveying disciplines as defined by the Royal Institution of Chartered Surveyors. While in the US, the real estate education system was heavily emphasized on business and financial management.

According to Rabianski [18], colleges and universities should provide at least three properties of academic aspects of education or formal education, including professional education provided by various entities in the real estate industry and job training. Institute of Surveyors Malaysia (ISM) has conducted a survey on graduates in estate management in 2001 and found that the performance of real estate graduates was below expectation from the perspective public and private organizations. The expectations from the academics and practitioners should be adjusted in order to close the gap between 'the text book world' and 'the real world'. Therefore, 'a new looked' real estate education is coming of age. All real estate community has to work together in developing the profession from the real estate graduates to the scope of real estate profession [19].

\section{B. Features of the Malaysian Real Estate Education System}

The real estate profession has began to rise just after the Independence Day, where a small group of professional served in valuation division undertaking real estate valuation for statutory purposes in Ministry of Finance that now known as Valuation and Property Services Department (VPSD). In 
1967, University Teknologi Mara (UiTM) has begun the first diploma program in real estate, while Universiti Teknologi Malaysia (UTM) first degree real estate program in 1973. Meanwhile, in 1996, Universiti Malaya commenced the first real estate program at degree level. These institutions have produced graduates who are now serving the real estate sector in the country.

Most of the graduates have been accepted by public and private sectors, and they hold important position in government agencies, and owners and major shareholder of many property consultant and valuation firm. The real estate program is designed to meet the requirements of the industry and thus, changes in the syllabus are sometimes reviewed to ensure its relevance to the industry needs [20].

\section{Competencies Required by Graduates}

Harvey, Burrows, and Green [21] report that, there is little agreement on the balance expected between the importance of graduates' persona characteristic and discipline specific technical knowledge. Though, various reviews of literature proposed and examining a number of competency's emphasizes on personal attributes required or expected of graduates [22]-[25].

Maes, Weldy, and Icenogle, [26] likewise, see oral communication, problem-solving skills and self-motivation are the three most important competencies required of graduates. Stasz [24] stressed that personal qualities, communication skills, problem-solving, and teamwork, as the most important competencies, but suggests that the workplace context determine their relative importance.

Joseph and Joseph [27], in a survey of 280 New Zealand graduate employers, found the top-ranked competencies in descending order were: willingness to learn; possessing the ability to work independently having a positive attitude; having good communication skills; and, being motivated. Hence, the literature suggests that employers of graduates now place major emphasis on generic, behavioral competencies, both in the recruitment of graduates for employment, as well as their performance on the job [25], [28]. As a consequence, undergraduate courses must seek to develop these competencies in order to meet the needs of business [29]. Weisz [25] found evidence of a link between degree programs that included work-based cooperative education and graduate employment, and found that employers expect generic competencies to be developed prior to employment. Interestingly, Weisz [25] noted little correlation between academic achievement and levels of generic skills, suggesting that employability is not necessarily related to academic ability.

Joseph and Joseph [27] report that, employers believe that educational institutions provide relevant employment experience for their business students, but remarkably, ascribe generic competencies a low level of importance. However, the level of competency expected of graduates by these employers, fell well below their perceived level of importance, suggesting that employers expect these competencies would be developed elsewhere in the curriculum and not necessarily through industry involvement.

\section{Generic Skills}

While there are no specific skills that are listed as generic skills, the Malaysian Institute of Higher Learning interprets generic skills as incorporating aspects of generic skills, which include non-academic skills such as leadership, teamwork, communication, and lifelong learning. It discussed briefly below are the seven traits of generic skills that are to be embedded in the syllabus taught at Institutes of Higher Learning.

Generic skills viewed as the managerial, intra-personal, communication and interpersonal skills that used to resolve workplace problems and to elicit the activities and processes performed by different stakeholder and all of which need to be accomplished through dialogue with stakeholders [30], [31]. Generic skills are intangible knowledge that complex to enumerate and transmit, as it relates to personal characteristics and includes judgment and experience. The literature defined generic skills as an internalised skills acquired with experience and practice [32], [33].

\section{MALAYSIAN MODEL ON THE IMPLEMENTATION OF GENERIC SKILLS}

The research refers to the Malaysian model on implementation generic skills in higher education. The study concentrates primarily on the acquisition of generic skills in the process of teaching and learning provided the initial evidence of the 'Embedded Model' that the best skills are transferred through integrated skills interdisciplinary courses rather than stand-alone subject to university students [4], [5], [34]. Graduates' perceptions concerning the integration of generic skills in this research, therefore examined in the industrial training.

In the Malaysian context, the generic skills specifically designated by the Ministry of Higher Education (MOHE), to be included in all degree programs, comprise seven skills as follows:

1) Communication skills in English;

2) Critical thinking and problem-solving skills;

3) Team-working skills;

4) Lifelong learning and information management skills;

5) Entrepreneurial skills;

6) Moral and professional ethics; and,

7) Leadership skills.

\section{Methodology}

\section{A. The Evolution of Real Estate Education}

The questionnaire is designed to gather information on graduates' perspectives on the adequate infusion and acquisition of the designated 'generic skills' in the teachinglearning process. The scales of interest are the seven categories of skills designated in the Malaysian model. For each scale or skill category, there are at least three items to ensure the reliability of the responses. More importantly, the distilling of groups of questions for each skill category allows for graduates to reflect on their own experiences. There are a total 34 scale items for training components.

\section{B. Pilot Test}

Prior to the distribution of the actual questionnaire, the 
questionnaire was pilot-tested on graduates of the real estate program. The pilot test was to ensure that the questions were clear and easily understood by the respondents. In general, it was observed that the selected respondents had no major difficulties in filling out the questionnaire. However, a few minor changes were made to the questionnaire to improve its format and facilitate analysis. To avoid any form of bias, the twenty respondents involved in the pilot survey were excluded from the final survey.

\section{Sampling Procedure}

A survey method was employed for the study, and structured questionnaires were distributed to graduates of the real estate program of public universities to obtain their feedback on the integration of generic skills in training. Graduates' perceptions are significant as they are regarded as accurate credible reporters of their activities and how much they have benefited from higher-education experience [35]. The target respondents were the current graduates of real estate of Universiti Teknologi Malaysia.

A wide range of recommendations regarding sample size in factor analysis have been made. These are usually stated in terms of either the minimum sample size $(\mathrm{N})$ for a particular analysis or the minimum ratio of $\mathrm{N}$ to the number of variables, $p$ i.e. the number of survey items being subjected to factor analysis [36]. Gorsuch (1983) [37] recommended five subjects per item, with a minimum of 100 subjects, regardless of the number of items. More demanding recommendations for sample size require a minimum of 10 subjects per item or just a large sample, ideally several hundred [38], [39].

200 of real estate graduates were completing the questionnaire, which passed the 0.95 of confidence level as determined by using Taro Yamane formula [40]. The accredited real estate program of recognized university in Malaysia represents a more appropriate choice for examining the adequacy of the integration of generic skills in the curriculum as they have largely been engaged in conventional methods of teaching and learning. Having gone through four years of university education, graduates of real estate would be able to comment and provide more valuable feedback on the integration of generic skills into the various courses of the program.

\section{Data Analysis}

Survey data were analyzed using the descriptive statistic to ensure the distributions of data related to the perception of real estate graduates on the seven generic skills. Furthermore, the inference statistic of variance analysis of Exploratory Factor Analysis was used to assess the acquisition and infusion of generic skills in the real estate program. Further analysis using factor analysis was used to determine whether there was any significant relationship based on the profile variables.

Survey data were analysed using the descriptive statistics to ensure the distributions of data related to the perceptions of the real estate graduate on the seven generic skills as designated by Ministry of Higher Education [41].

Factor analysis can be described as an organized measure mutual facilitation. Traditionally factor analysis was used to explore the possibility of an underlying structure of interconnected set of variables without imposing any preconceived structure on the outcome [42]. By doing exploratory factor analysis (EFA), the number of constructs and underlying structural factors identified.

The goals of factor analysis is to determine the number of variables influence domain basis, to measure the extent to which each variable is correlated to the factors, and to obtain information about their nature from observing which factors contribute to the performance on which variables [43].

\section{RESULTS AND INTERPRETATION}

\section{A. Demographic Profiles of Respondents}

TABLE I: THE DEMOGRAPHIC PROFILES

\begin{tabular}{lll}
\hline \hline Items & & Percentage (\%) \\
\hline Gender & Male & 35 \\
& Female & 65 \\
Ethnic & Malay & 69 \\
& Chinese & 21 \\
& Indian & 7 \\
& Others & 3 \\
Job related field & Yes & 64 \\
& No & 36 \\
\hline \hline
\end{tabular}

From the mean scores reported in Table II, the infusion of generic skills in training is also revealed to be inadequate. Most items have mean scores below 3, indicating that respondents at large disagreed on the adequacy of skills embedded in training programs. Items listed under the moral and professional ethics skills in particular have mean scores above 3 , indicating that, on average, most respondents agree that this skill has been well imparted and acquired via training.

TABLE II: THE DESCRIPTIVE STATISTIC OF TRAINING COMPONENT

\begin{tabular}{|c|c|}
\hline Items for training component & Mean \\
\hline $\begin{array}{l}\text { I. Communication skills ( } 6 \text { items scale with Mean range } \\
\text { between } 2.21-2.82 \text { ) }\end{array}$ & 2.21 \\
\hline $\begin{array}{l}\text { Sample item: Communication at workplace was mainly in } \\
\text { English }\end{array}$ & \\
\hline $\begin{array}{l}\text { II. Critical thinking and problem solving ( } 4 \text { items scale } \\
\text { with Mean range between } 2.84-3.43 \text { ) }\end{array}$ & 2.84 \\
\hline Sample item: Tasks given were problem-centred & \\
\hline $\begin{array}{l}\text { III. Team working skills ( } 4 \text { items scale with Mean range } \\
\text { between } 2.50-3.38)\end{array}$ & 3.38 \\
\hline $\begin{array}{l}\text { Sample item: I had opportunities to be involved in } \\
\text { teamwork }\end{array}$ & \\
\hline $\begin{array}{l}\text { IV. Lifelong learning and information management skills }(6 \\
\text { items scale with Mean range between } 2.53-3.34)\end{array}$ & 2.54 \\
\hline Sample item:My work involved regular use of computers & \\
\hline $\begin{array}{l}\text { V. Entrepreneurial skills ( } 4 \text { items scale with Mean range } \\
\text { between } 2.28-2.63 \text { ) }\end{array}$ & 2.60 \\
\hline Sample item:I was directly involved in specific projects & \\
\hline $\begin{array}{l}\text { VI. Moral and professional ethic skills }(5 \text { items scale with } \\
\text { Mean range between } 2.94-3.43 \text { ) }\end{array}$ & 3.34 \\
\hline $\begin{array}{l}\text { Sample item:Punctuality to work was strictly monitored by } \\
\text { the organization supervisor/school leadership }\end{array}$ & \\
\hline $\begin{array}{l}\text { VII. Leadership skills(5 items scale with Man range } \\
\text { between } 2.28-3.25)\end{array}$ & 2.60 \\
\hline $\begin{array}{l}\text { Sample item:I had opportunities to manage tasks } \\
\text { independently }\end{array}$ & \\
\hline
\end{tabular}

In general, the précis of means signify that, generic skills infused in training program has not met the needs of the 
undergraduates, with the exemption for a few skills competencies. This is the indication that the assimilation of skills in the formal curriculum has not been completely realized.

Exploratory factor analysis is conducted to remove items that have low factor loadings. Hair, Anderson, Tatham, and Black [43] suggested that, with new factor loadings, a Cronbach's alpha of at least 0.60 is fulfilled by all factors. The principal components analysis with varimax rotation is used for the extraction of the factor dimensions.

According to Hair, Anderson, Tatham, and Black [44], items were removed if factor loadings were less than 0.4 . The non-standardized Cronbach's alpha [45] determined the scale for reliabilities that is widely used [46] and preferred [47].Values of between 0.5 and 0.9 for the seven factors for both datasets are considered sufficient [48] for exploratory research since they exceed the 0.5 threshold. Of the dimensions shown in Tables II for training components, six scales had Cronbach's Alpha values above 0.7.

TABLE III: THE FACTOR ANALYSIS OF PERCEPTIONS ON SKILL INFUSED THROUGH TRAINING

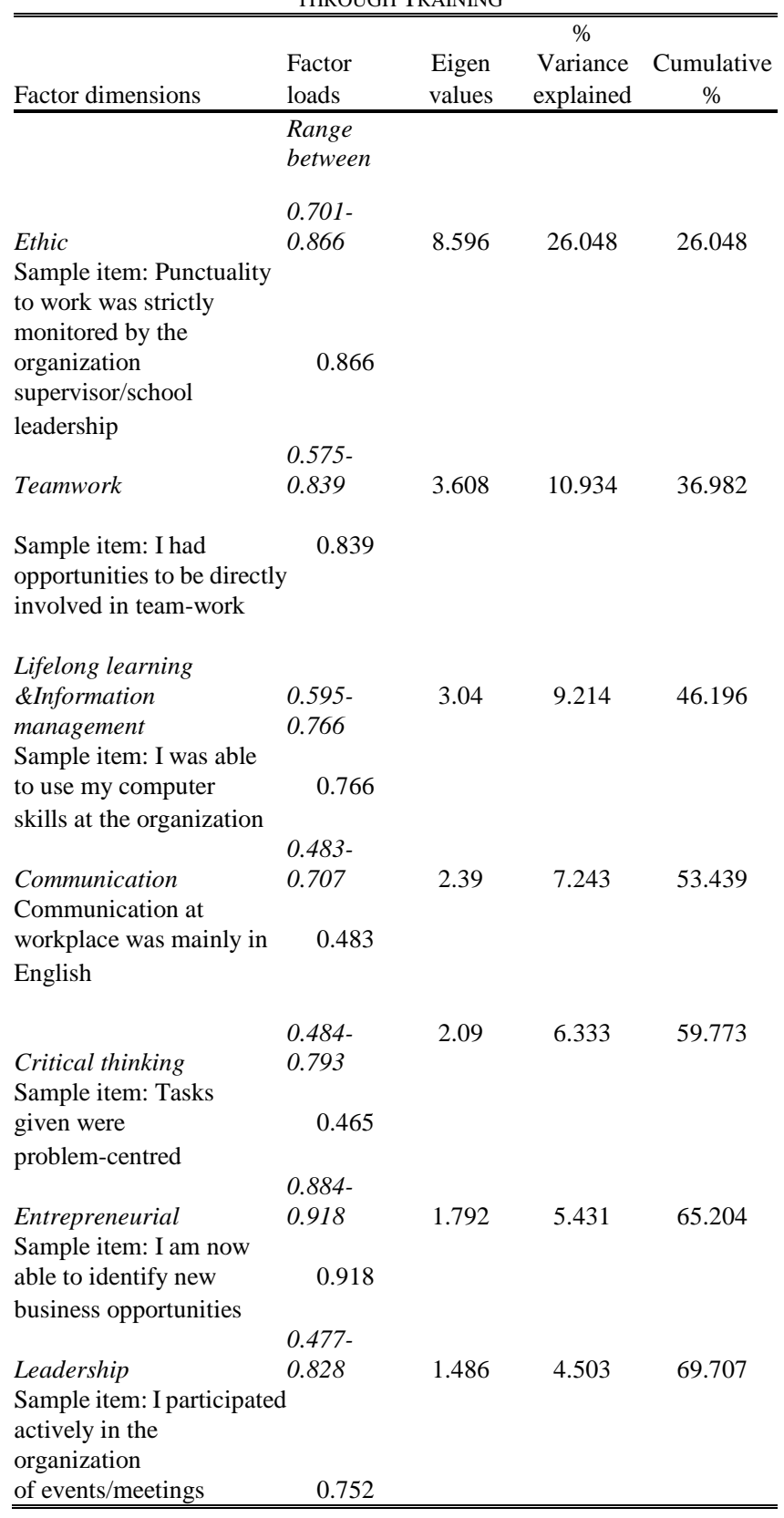

The naming of the factor loading matrix in this study is relatively straightforward since the items clustered reflect closely the seven generic skills. The seven-factor dimensions are thus communication skills, critical thinking and problem-solving skills, team-working skills, lifelong learning and information management skills, entrepreneurship skills, moral and professional ethics, and leadership skills. Tables III show that, all seven factors explain 69.707 per cent of the total variance of the infusion and acquisition of generic skills by the training program.

Moral and professional ethics ranks first, explaining 26.048 per cent of the total variance. This is followed by team working skills, and lifelong learning and management skills that explain 10.934 per cent and 9.214 per cent of the total variance, respectively. This is not surprising since the study by Koo, Pang, and Fadhil [6] indicates that employers are willing to assist students better able to manage information. As such, many students do acquire information management skills in the course of their practical training.

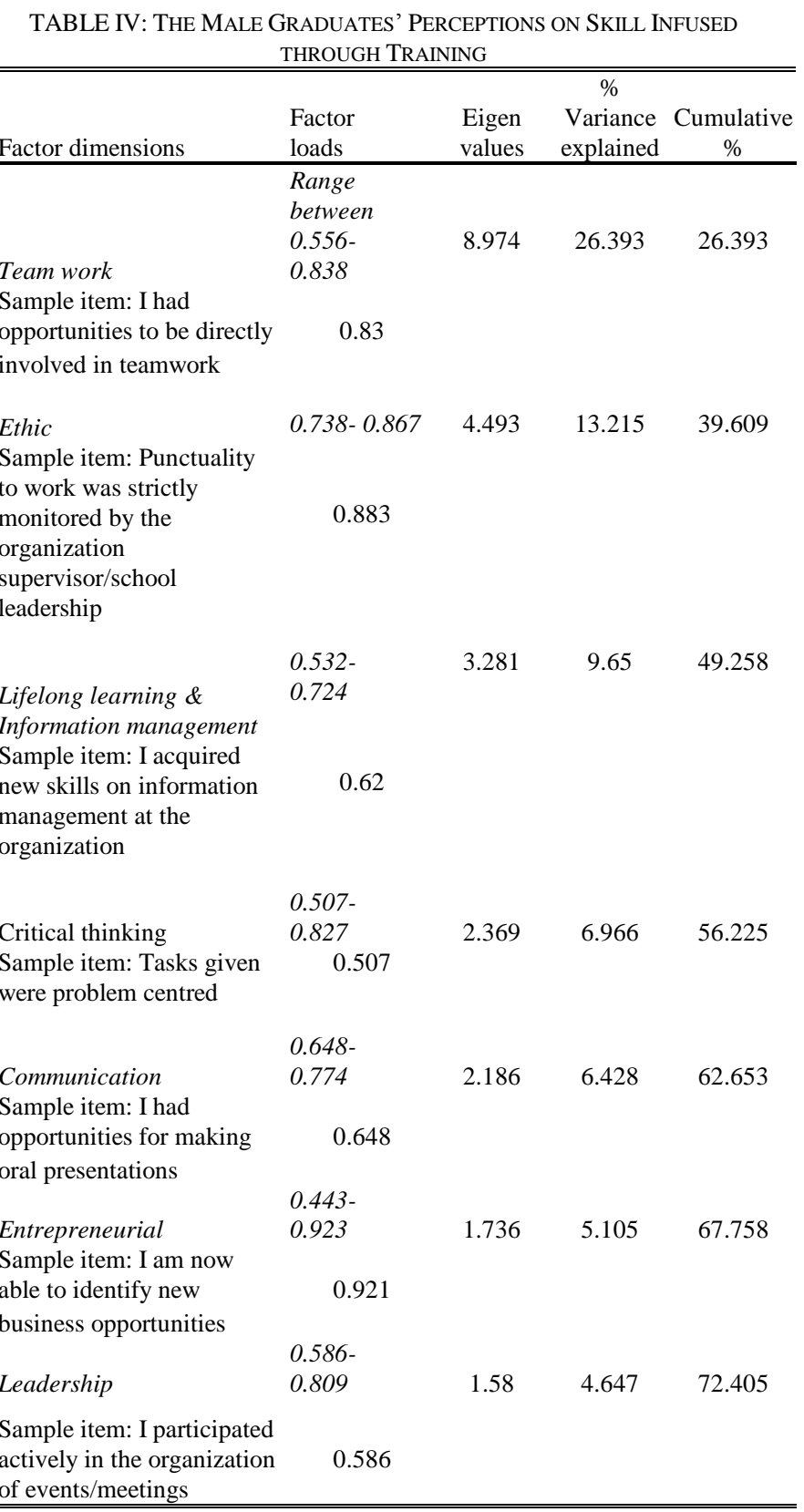

The findings suggest that the infusion of skills via training 
are not only highly concentrated on specific skills but that they also complement each other once the type of skill is considered. As such, practical training is an equally important component of degree program to ensure that students are well equipped with the designated skills.

TABLE V: The Female GraduAtes’ Perceptions on SKILl INFUSED THROUGH TRAINING

\begin{tabular}{|c|c|c|c|c|}
\hline Factor dimensions & $\begin{array}{l}\text { Factor } \\
\text { loads }\end{array}$ & $\begin{array}{l}\text { Eigen } \\
\text { values }\end{array}$ & $\begin{array}{l}\% \\
\text { Variance } \\
\text { explained }\end{array}$ & $\begin{array}{c}\text { Cumulative } \\
\%\end{array}$ \\
\hline $\begin{array}{l}\text { Ethic } \\
\text { Punctuality to work was } \\
\text { strictly monitored by the } \\
\text { organization supervisor }\end{array}$ & $\begin{array}{l}\text { Range } \\
\text { between } \\
0.46- \\
0.843\end{array}$ & 8.534 & 25.1 & 25.1 \\
\hline Teamwork & $\begin{array}{l}0.53- \\
0.83\end{array}$ & 3.543 & 10.42 & 35.52 \\
\hline $\begin{array}{l}\text { I had opportunities to be } \\
\text { directly involved in } \\
\text { teamwork }\end{array}$ & 0.83 & & & \\
\hline $\begin{array}{l}\text { Lifelong learning \& } \\
\text { Information } \\
\text { management } \\
\text { I was able to use my } \\
\text { computer skills at the }\end{array}$ & $\begin{array}{l}0.514- \\
0.834\end{array}$ & 3.01 & 8.853 & 44.373 \\
\hline $\begin{array}{l}\text { Critical thinking } \\
\text { Tasks given were } \\
\text { problem-centred }\end{array}$ & $\begin{array}{l}0.474- \\
0.794\end{array}$ & 2.525 & 7.426 & 51.799 \\
\hline $\begin{array}{l}\text { Communication } \\
\text { Communication at } \\
\text { workplace was mainly in } \\
\text { English }\end{array}$ & $\begin{array}{l}0.603- \\
0.696\end{array}$ & 2.057 & 6.051 & 57.85 \\
\hline Leadership & $\begin{array}{l}0.505- \\
0.847\end{array}$ & 1.751 & 5.15 & 63.001 \\
\hline $\begin{array}{l}\text { manage tasks } \\
\text { independently }\end{array}$ & 0.504 & & & \\
\hline $\begin{array}{l}\text { Entrepreneurial } \\
\text { I am now able to identify } \\
\text { new business } \\
\text { opportunities }\end{array}$ & 0.916 & 1.488 & 4.376 & 67.376 \\
\hline
\end{tabular}

The analysis is further extended based on gender for training components to obtain unique clusters of graduates' perceptions.

In the case of skills embedded in the training component (Tables IV), the male gender perceived team-working, lifelong learning and information management, and moral and professional ethics skills as more important, and they are ranked as the top three factors. As for the female gender, moral and professional ethics remains as the most important skills acquired by them through training (Table V).

In the case of skills embedded in the training component (Tables VI), the Malays perceived team-working as more important, and they are ranked first, with a total variance explained of 29.345 per cent. Factor two appeared to measure moral and professional ethics skills consisting of five important skills, with a total variance explained of 9.388 per cent.

When training is considered (Tables VII), non-Malays perceived moral and professional ethics as most importantly infused and acquired, as that which is obtained for the overall sample. For the non-Malays, moral and professional ethic ranked first that explain 24.154 per cent of the total variance.

Factor two appeared to measure team working skills consisting of four competencies, with a total variance explained of 11.906 per cent. Factor three appeared to measure lifelong learning and information management, with a total variance explained of 9.52 per cent.

TABLE VI: THE FACTOR ANALYSIS OF MALAY GRADUATES' PERCEPTIONS ON SKILL INFUSED THROUGH TRAINING

\begin{tabular}{|c|c|c|c|c|}
\hline Factor dimensions & $\begin{array}{l}\text { Factor } \\
\text { loads }\end{array}$ & $\begin{array}{l}\text { Eigen } \\
\text { values }\end{array}$ & $\begin{array}{c}\% \\
\text { Variance } \\
\text { explained }\end{array}$ & $\begin{array}{c}\text { Cumulative } \\
\%\end{array}$ \\
\hline Teamwork & $\begin{array}{l}\text { Range } \\
\text { between } \\
0.447- \\
0.781\end{array}$ & 9.684 & 29.345 & 29.345 \\
\hline $\begin{array}{l}\text { I had opportunities to be } \\
\text { directly involved in } \\
\text { teamwork }\end{array}$ & 0.72 & & & \\
\hline $\begin{array}{l}\text { Ethic } \\
\text { Donlt }\end{array}$ & $\begin{array}{l}0.66- \\
0.845\end{array}$ & 3.098 & 9.388 & 38.733 \\
\hline $\begin{array}{l}\text { Punctuality to work was } \\
\text { strictly monitored by the } \\
\text { organization } \\
\text { supervisor/school } \\
\text { leadership }\end{array}$ & 0.66 & & & \\
\hline Leadership & $\begin{array}{l}0.507- \\
0.879\end{array}$ & 2.985 & 9.046 & 47.779 \\
\hline
\end{tabular}

I had opportunities to

manage tasks independently $\quad 0.879$

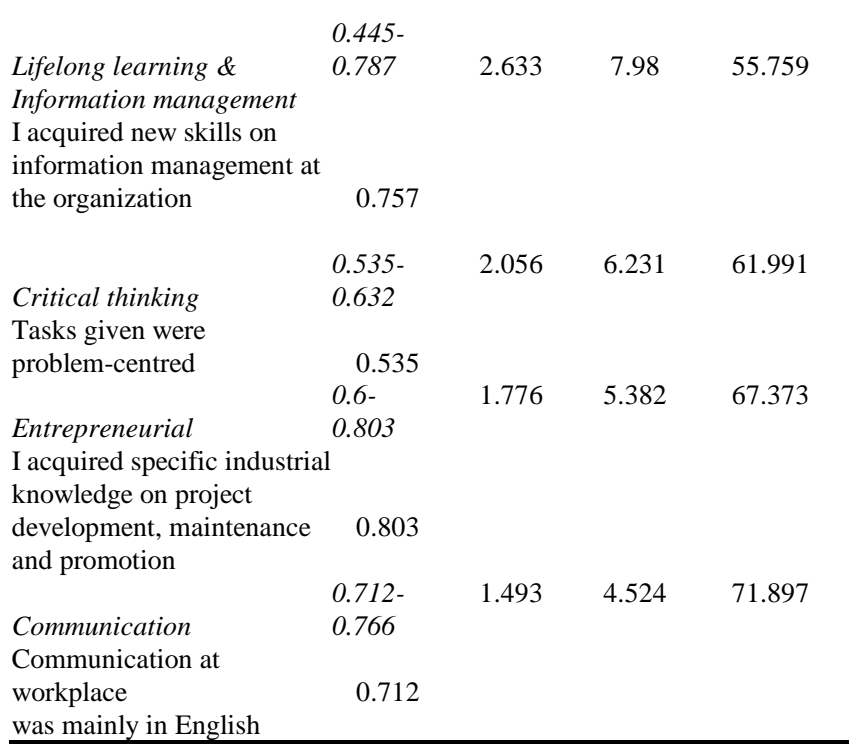

As for training, the items clustered in the seventh factor are, I wrote reports at work mainly in English and communication at the workplace was mainly in English, represented only 4.524 per cent of the total variance explained. The lack of integration of communication skills in training as perceived by graduates must be given due to attention since this is also a skill that is not sufficiently infused. As general, when training is considered, both Malays and non-Malays perceived moral and professional ethics as most importantly infused and acquired, as that which is obtained for the overall sample.

Factor one of Table VIII, appeared to measure moral and professional ethics skills, and with a total variance explained 
of 26.497 percent. Factor two appeared to measure team-working skills, appeared to have a total of variance 11.275 per cent.

Lifelong learning \& Information management skills which are ranked third in Table VIII represented 9.043 per cent of the total variance explained. The leadership skills was the item loaded into seventh factor, represented only 4.161 per cent of the total variance explained. The sum of eigenvalue associated with each of the seven factors was 71.044 per cent.

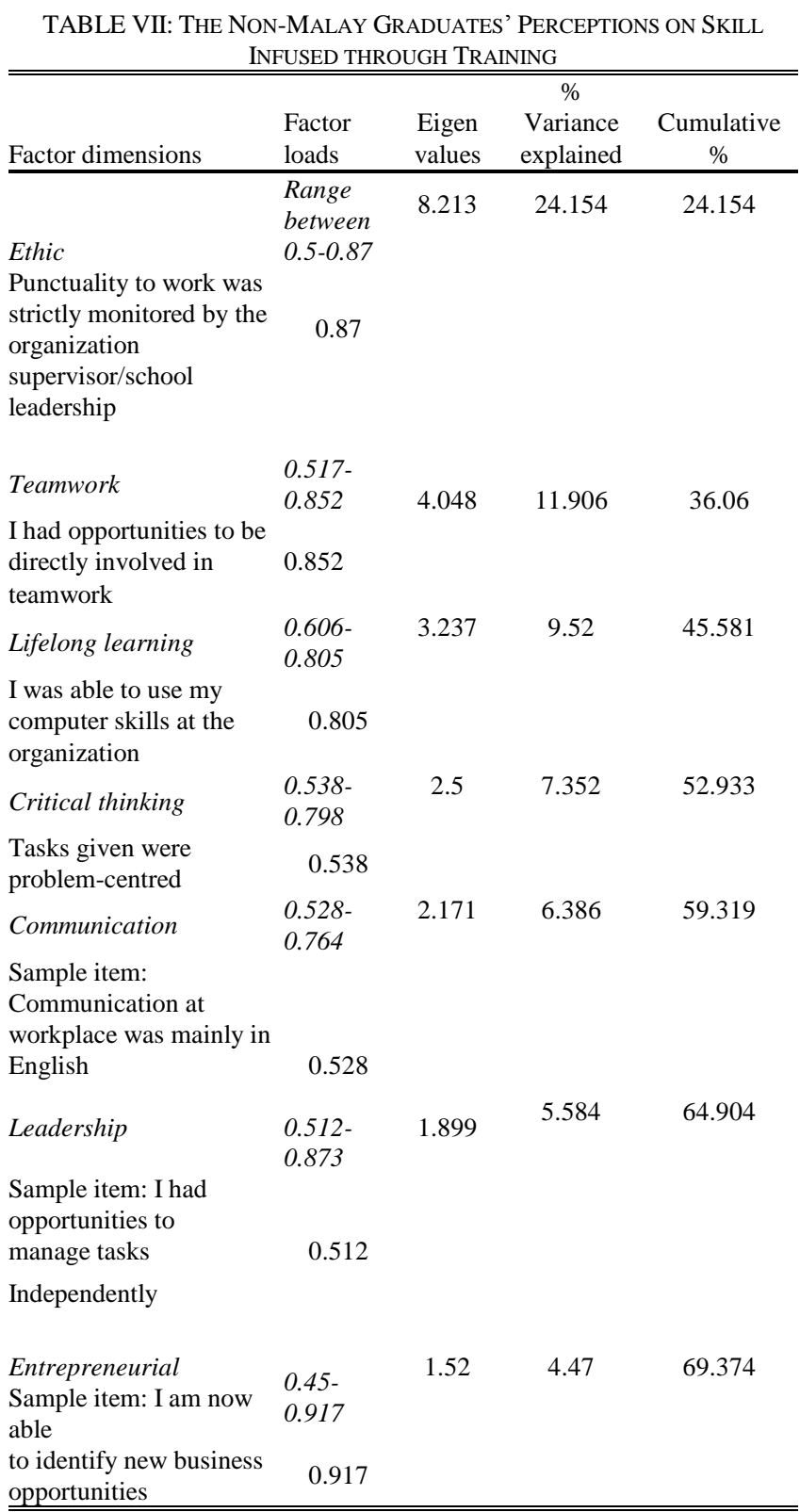

\section{VERIFICATION AND VALIDATION}

Focus group discussion has been conducted to verify and validate the factor dimension and findings of this study. Nine experts consisting of industry representatives, real estate professional's bodies, and academia were involved to verify the findings. In general, the précis of the analyses signified that, generic competencies infused in the real estate training program has not met the needs of the graduates, with the exemption for a few skills competencies such as moral and professional skills, teamwork skills, and lifelong learning and information management skills.
The lack of infusion and acquisition of entrepreneurial skills, leadership skills, and communication skills deserve attention. Real estate education should reinforce the continuing need for training that focuses on the development of human skills along with self technical knowledge required for a given industry.

TABLE VIII: The PERCEPTION OF THE GRAdUATE Who HAD Job Related ON THE INFUSION OF GENERIC SKILLS EMBEDMENT VIA TRAINING

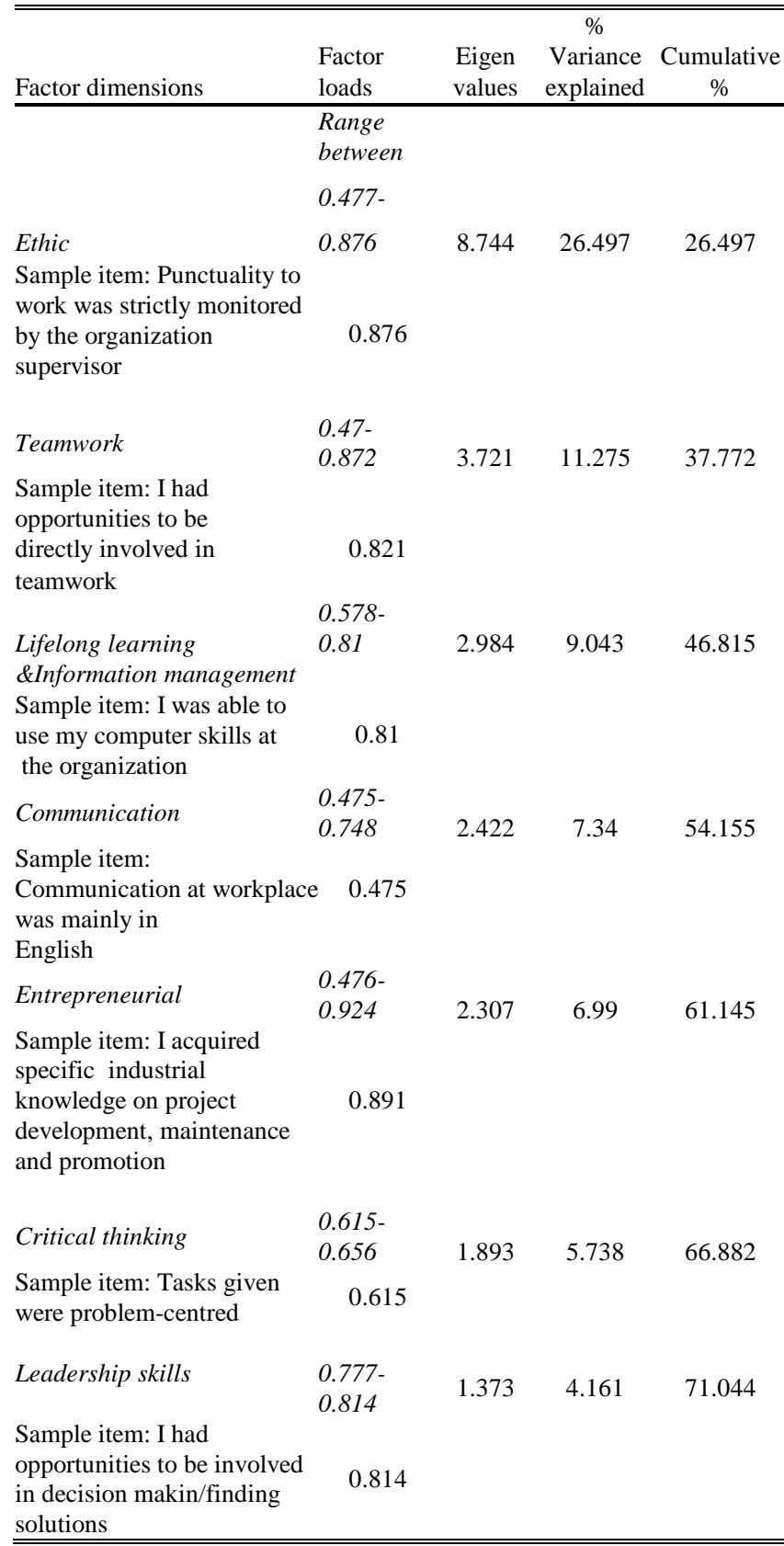

\section{CONCLUSION}

Given the findings, selectivity or well-structured placements in organizations for training purposes should be exercised to ensure adequate exposure and better acquisition of skills. In this respect, students should target placements beyond public to private organizations, large concerns of the industry and relevant organizations to the program or discipline to encourage deeper learning and ensure maximization of learning capacity at the workplace. The volume scholarly commentary on the need for greater 
emphasis on soft skills in the training and education of real estate to validate the importance of the human factor as a viable focal point for predicting the eventual success of the project. The real estate organizations need to identify specific strategic objectives for training before the start of training and measure the added value to the strategic goals set after the delivery of content.

While it is acknowledged that the relatively low response rate means we need to be cautious with any interpretation of these survey results, indicating that respondents at large disagreed on the adequacy of skills embedded in training. Most respondents agree that moral and professional ethic skills and teamwork skills have been well imparted and acquired via formal training.

There are several immediate issues that can be addressed by public universities to ensure a more successful integration of soft skills in the real estate curriculum. There is a need for instructors to review their strategies for the integration of skills that are inadequately infused and acquired by students.

The study therefore brings to the fore the need for improvement in the real estate program. Specifically, the current instructional and assessment strategies still require change that can ensure a better integration of skills. A mere review of the curriculum design, identifying what skill elements have to be embedded to ensure that the students develop the entire range of skills throughout the duration of the program, to reflect the various soft skills elements obviously do not suffice if the teaching-learning strategies remain weak.

\section{REFERENCES}

[1] J. Dasso and L. Woodward, "Real estate education: past, present, and future-the search for a discipline," The Appraisal Journal, vol. 49, no. 3, pp. 413-425, 1981.

[2] C. Manning, "Improving real estate and other business courses through targeted student assessment," Journal of Real Estate Practice and Education, vol. 5, no. 1, pp. 27-44, 2002.

[3] N. Bennett, E. Dunne, and C. Carre, "Patterns of core and generic skill provision in higher education," Higher Education, vol. 37, pp. 71-93, 1999.

[4] J. F. Leckey and M. A. McGuigan, "Right tracks-wrong rails: The development of generic skills in higher education," Research in Higher Education, vol. 38, no. 3, pp. 365-378, 1997.

[5] D. Kember, D. Y. P. Leung, and R. S. F. Ma, "Characterizing learning environments capable of nurturing generic capabilities in higher education," Research in Higher Education, vol. 48, no. 5, pp. 609-632, 2006.

[6] Y. L. Koo, V. Pang, and M. Fadhil. (2009). Employer perceptions on graduate literacies in higher education in relation to the workplace. In English for specific purposes World. [Online]. Available: http://www.esp-world.info/Articles_20/DOC/Koo_vp_employer_Jour nal18Oct09.pdf.

[7] T. H. Chiam, "Employability and learn ability of Malaysian graduates at the workplace," presented at the 9th Malaysian education summit: World-class education in Malaysia: Creating a new breed of human capital to transform Malaysia into a centre of knowledge and technology excellence, Sunway Pyramid Convention Centre, Kuala Lumpur, Malaysia, 21-22 March, 2005.

[8] Economic Planning Unit, "Malaysia and the knowledge economy: Building a world-class higher education system," Report no. 40397-MY, Human Development Sector, East Asia and Pacific Region. World Bank, Washington DC.2007.

[9] H. E. Lim and A. B. Normizan, "Unemployment duration of graduates of Universiti Utara Malaysia: The impact of English language proficiency," Malaysia Journal of Economic Studies, vol. 41, no. 1-2, pp. 1-20, 2004

[10] M. Marina, "A need to rebrand our graduates," The Star, February 28, 2007.
[11] A. R. Norizan, A. Hazita, A. A. M. Sallehhudin, F. F. Wong, and Y Azizah, "The quality and marketability value of local graduates: Perspectives from the Malaysian employers," presented at the 6th SEAAIR Annual Conference, Langkawi, Malaysia, September 5-7, 2006.

[12] A. H. Quek, "Learning for the workplace: A case study in graduate employees' generic competencies," Journal of Workplace Learning, vol. 17, no. 4, pp. 231-243, 2005.

[13] J. Butler, K. L. Guntermann, and M. Wolverton, "Integrating the Real Estate curriculum," Journal of Real Estate Practice and Education, vol. 1, no. 1, pp. 51-66, 1998.

[14] C. H. Quah, N. Aizzat, E. C. Guok, and J. Ignatius, "Employers' preference for foreign trained graduates - myth or reality?" European Journal of Scientific Research, vol. 34, no. 3, pp. 372-383, 2009.

[15] T. Musil, "Integrating business school curricular resources into real estate practitioner professional development," Journal of Real Estate Practice in Education, vol. 8, no. 1, pp. 131-49, 2005.

[16] M. Weinstein, "Examination of top real estate MBA programs: Implications for improving education for practitioners, an analysis of real estate," presented at the Eighteenth Annual Meeting of the American Real Estate Society, Naples, Florida, April 10-13, 2002.

[17] L. A. Galuppo and E. M. Worzala, "A study into the important elements of a masters degree in real estate," Journal of Real Estate Practice and Education, 2004

[18] J. S. Rabianski, "Education in the real estate profession," Real Estate Issues, Summer, vol. 28, p. 21, 2003.

[19] H. M. Ali and B. Alias, "Real estate education in Malaysia: A new paradigm," presented at International Real estate Research Symposium, Kuala Lumpur, 2006.

[20] M. A. Hishamuddin et al., "Real estate graduates in Malaysian corporate companies," presented at International Real Estate Research Symposium (IRERS), Benchmarking, Innovating and Sustaining Real Estate Market Dynamics, PWTC Kuala Lumpur, Malaysia, April 28-30, 2008

[21] B. Alison and D. M. Green, "Criteria of quality," University of Central England in Birmingham, Centre for Research into Quality, 1992.

[22] P. Meade and R. Andrews, "Measuring employer satisfaction in higher education," The Quality Magazine, pp. 52-53, 1995.

[23] M. Sweeney and P. Twomey, "Preparing graduates for 2020: The role of cooperative education," presented at the 10th World Conference on Cooperative Education, Cape Town, South Africa, August, 1997.

[24] C. Stasz, "Do employers need the skills they want? Evidence from technical work," Journal of Education and Work, vol. 10, no. 3, pp. 205-223, 1997.

[25] M. Weisz, "The added value of undertaking cooperative education year: The measurement of student attributes," Melbourne, Australia: Royal Melbourne Institute of Technology, 1999.

[26] J. D. Maes, T. G. Weldy, and M. L. Icenogle, "The managerial perspective: Oral communication is the most important for business students in the workplace," Journal of Business Communication, vol. 34, no. 1, pp. 67-80, 1997.

[27] M. Joseph and B. Joseph, "Employer's perception of service quality in higher education," Journal of Marketing for Higher Education, vol. 8, no. 2, pp. 1-13, 1997.

[28] M. A. Raymond, D. E. McNabb, and C. F. Matthaei, "Preparing graduates for the workforce: The role of business education," Journal of Education for Business, pp. 202-206, 1993.

[29] B. F. Haber, "Alternative assessment in accounting," Business Education Forum, vol. 48, no. 2, pp. 23-25, 1993.

[30] A. Jeyaraj. (2010). Business process elicitation, modelling and re-engineering: teaching and learning with simulated environments. Journal of Information Systems Education. Summer. [Online] Available:

http://findarticles.com/p/articles/mi_qa4041/is_201007/ai_n5506924 $5 /$

[31] D. Joseph, S. Ang, R. H. L. Chang, and S. A. Slaughter, "Practical intelligence in IT: Assessing soft skills of IT professionals," Communications of the ACM, vol. 53, no 2, pp. 149-154, 2010.

[32] S. Kajnc and M. Svetlicic, "What it takes to run an EU presidency: Study of competencies in Slovenia's public administration," Administrative Culture, vol. 11, no 1, pp. 84-109, 2010.

[33] S. Ranade, C. Tamara, E. Castiblaqnco, and A. Serna. (February 2010) Mapping competencies. Mechanical Engineering. [Online]. Available: http://memagazine.asme.org/Articles/2010/february/Mapping_Compe tencies.cfm

[34] T. Lisa, "Courses and instruction affecting critical thinking," Research in Higher Education, vol. 40, no. 2, pp. 185-200, 1999. 
[35] C. Smith and D. Bath, "The role of the learning community in the development of discipline knowledge and generic graduate outcomes," Higher Education, vol. 51, pp. 259-286, 2006.

[36] R. C. MacCallum, K. F. Widaman, S. Zhang, and S. Hong, "Sample size in factor analysis," Psychological Methods, vol. 4, no. 1, p. 84, 1999.

[37] R. L. Gorsuch, Factor Analysis, 2nd Ed., Hillsdale, NJ: Lawrence Erlbaum, 1983.

[38] B. S. Everitt, "Multivariate analysis: the need for data and other problems," British Journal of Psychiatry, vol. 126, pp. 237-240, 1975.

[39] E. E. Cureton and R. B. D'Agostino, Factor Analysis: An Applied Approach, Hillsdale, NJ: Erlbaum, 1983.

[40] T. Yamane, Statistics: An Introductory Analysis, 2nd Ed., New York: Harper and Row, 1973.

[41] Ministry of Higher Education, Development of soft skills for institutions of higher learning, Selangor: Universiti Putra Malaysia.2006.

[42] C. Dennis, "The essentials of factor analysis," Cassell Educational, 1990.

[43] C. Robert, "Exploratory factor analysis," Handbook of Applied Multivariate Statistics and Mathematical Modeling, pp. 265-296, 2000.

[44] J. F. Hair, R. E. Anderson, R. L. Tatham, and W. C. Black, Multivariate Data Analysis, 5th Ed., Englewood Cliffs, NJ: Prentice-Hall International, Inc.1998.

[45] L. J. Cronbach, "Coefficient alpha and the internal structure of tests," Psychometrika, vol. 16, no. 3, pp. 297-334, 1951.

[46] A. Aron and E. N. Aron, Statistics for Psychology, New Jersey: Prentice Hall, 1994.

[47] G. A. Morgan and O. V. Griego, Easy Use and Interpretation of SPSS for Windows, London: Lawrence Erlbaum Associates, 1998.
[48] J. Nunnally, Psychometric Theory, New York: McGraw- Hill, 1978.

Wilson Rangga Anthony Jiram received his B.Sc. of property management and M.Sc. degree of real estate at Universiti Teknologi Malaysia. Currently, he is doing Ph.D. in real estate at Universiti Teknologi Malaysia, Malaysia. His current research is focused on real estate education. $\mathrm{He}$ is also interested in housing and property management area and has published several research papers on aforementioned topics.

Ahmad Ariffian Bujang is currently an associate professor at Faculty Geoinformation and Real Estate in Universiti Teknologi Malaysia (UTM). $\mathrm{He}$ also is a registered valuer under Board of Valuers, Appraisals and Estate Agents Malaysia. He received his Ph.D. in Universiti Malaya. His specialization is in valuation and property investment. He is also interest in statutory valuation. He has published several research papers and books on aforementioned topics.

Hasmah Abu Zarin received her BSc degree at Franklin University, Columbus Ohio, U.S.A. in real estate and her master degree in land economy at Abeerden University, Scotland, UK. Currently, she is a senior lecturer at Universiti Teknologi Malaysia. Her current research is focused on valuation, economy and planning. She is also interested in sustainability area and has published several research papers on aforementioned topics. She is a member of Institution of Surveyors Malaysia from 1999 until now.

Azlan Abdul Latib is currently a senior lecturer at the Department of Technical and Engineering, Faculty of Education, Universiti Teknologi Malaysia. He received his Ph.D. and M.Ed. in technical and vocational education at Universiti Teknologi Malaysia, Malaysia. 